\title{
Study of vaginal misoprostol for labour induction in intra uterine fetal demise
}

\author{
Chandrashekhar Tharihalli*, Shreelatha Bhat
}

Department of Obstetrics and Gynecology, VIMS, Bellary 583104, Karnataka, India

Received: 23 November 2016

Accepted: 20 December 2016

\author{
*Correspondence: \\ Dr. Chandrashekhar Tharihalli, \\ E-mail: cstobg@gmail.com
}

Copyright: (c) the author(s), publisher and licensee Medip Academy. This is an open-access article distributed under the terms of the Creative Commons Attribution Non-Commercial License, which permits unrestricted non-commercial use, distribution, and reproduction in any medium, provided the original work is properly cited.

\begin{abstract}
Background: Intrauterine fetal demise (IUFD) is the most undesirable consequence of pregnancy which causes psychological distress to mother and family. It also carries risk of infection and DIC. In literature, various methods have been described to manage the cases of IUFD. Practically prostaglandin analogues are routinely used for induction of labour in cases of IUFD. The objectives of this study were to assess the effectiveness and safety of vaginal misoprostol for induction of labour in IUFD.

Methods: In this prospective study, consecutive series of 100 women with IUFD $\geq 28$ weeks of gestation are studied. Detailed clinical history, physical examination and investigations are recorded. All selected cases were induced with vaginal misoprostol $50 \mu \mathrm{g}$ and the doses are repeated every 6th hourly depending on uterine contractions and Bishop's score changes.

Results: The average induction to delivery interval is 14.68 hours. All women delivered within 40 hours of administration of first dose of misoprostol with $47 \%, 86 \%$ and $100 \%$ delivering within 12 hours, 24 hours and 40 hours respectively. There was significant correlation between mean induction delivery interval and maternal age, parity and Bishop's score. Minor side effects like chills and fever were noted in $5 \%$ of patients and retained placenta and atonic PPH was seen in $2 \%$ each.

Conclusions: The low dose vaginal misoprostol for induction of labour in IUFD is a safe, effective and cost effective regimen.
\end{abstract}

Keywords: Bishop's score, Induction of labour, IUFD, Misoprostol

\section{INTRODUCTION}

The death of a formed fetus is one of the most emotionally devastating events for mother and clinicians. When a baby dies in utero the options are either to wait for labour to start spontaneously or to induce the labour. About $80 \%$ of women will deliver within 3 weeks of fetal death. But if fetal death occurs inutero without expulsion for several weeks then such retention of the fetus is associated with emotional distress and grief reaction which may be severe. If the rupture of fetal membranes occurs the risk of intrauterine infection increases and also there is a time related risk of consumption coagulopathy. ${ }^{1}$
This may have implications for counseling about the risks and management for any future pregnancies. ${ }^{2}$ In modern obstetrical practice medical induction of labor is recommended in case of intra uterine fetal demise. The use of oxytocin for induction of labour in IUFD is often difficult, painful and less successful especially in cases of early gestation, as uterus is less sensitive to oxytocin before term. The availability of prostaglandins has facilitated delivery options for patients with fetal deaths especially in the presence of unfavorable cervix. Misoprostol, a synthetic prostaglandin E1 analogue, has been found to be safe and effective for induction of labour in cases of IUFD. Its cost effectiveness, stability at 
room temperature and ease of availability and administration makes it an ideal drug for induction in cases of IUFD. Vaginal misoprostol is very effective because peak levels are reached slowly and sustained for long duration of time. It also has the advantage of less gastrointestinal side effects and greater bioavailability as compared to other routes of administration. This active approach will virtually eliminate the possibility of infection and consumptive coagulopathy and to some extent psychological stress involved in IUFD.

\section{METHODS}

In this prospective study, a consecutive series of 100 women with intrauterine fetal demise $\geq 28$ weeks of gestation during the period of $1^{\text {st }}$ August 2012 to $30^{\text {th }}$ July 2014 are studied. Study was conducted on patients who are admitted in Department of Obstetrics and Gynecology, VIMS, Bellary. All women were counseled regarding induction and options available for induction. All advantages and disadvantages of induction methods, complications and side effects of drug were also explained. All cases were subjected to detailed history taking and clinical examination. Ultrasound confirmation of intra uterine fetal demise was obtained. Consent was taken after counseling the patients. Patients were administered misoprostol $50 \mu \mathrm{g}$ in the posterior fornix. The dose is repeated every 6th hourly depending on changes in Bishop's score and uterine contraction. If the Bishop's score is more or equal to eight or if the contractions are $>2$ in ten minutes lasting for $\geq 40$ seconds, then no further doses of misoprostol were administered. A maximum of six doses were allowed to administer. The side effects like gastrointestinal side effects, shivering and fever which occurred during induction were noted.

Also complications like retention of placenta, $\mathrm{PPH}$ or placental abruptions were noted. The need for surgical intervention for removal of the placenta or any other medical intervention used were documented. If delivery does not occur after this regimen, then based on clinical situation appropriate method was used for termination of pregnancy. Any complications during period of induction and till 24 hours after delivery were reported. Routine antibiotics were given during the course of induction and after delivery. Patients were discharged after 24 hours of delivery or later depending on clinical condition of the patient. The data like maternal age, parity, gestational age, Bishop's score, birth weight, induction to delivery interval were analyzed using the SPSS 20 for windows statistical package. Variables that were normally distributed are presented as means with standard deviation and ranges. For assessment of correlations between multiple variables and induction delivery interval multiple regression analysis was used. The induction to delivery interval was used as the dependent variable subsequent to $\log$ transformation. Differences were regarded as statistically significant if $\mathrm{P}$ value $<0.05$.

\section{RESULTS}

In present study we studied 100 consecutive women with intra uterine fetal demise after 28 weeks of gestation who are induced with vaginal misoprostol $50 \mu \mathrm{g}$ during the period of 1st August 2012 to 31st July 2014. The patient characteristics are as follows:

Table 1: Age wise distribution.

\begin{tabular}{|lll|}
\hline Age group & Frequency & Percent \\
\hline Up to 20 years & 26 & 26.0 \\
\hline $21-25$ years & 47 & 47.0 \\
\hline $26-30$ years & 24 & 24.0 \\
\hline $31-35$ years & 3 & 3.0 \\
\hline Total & 100 & 100.0 \\
\hline
\end{tabular}

The age group ranged from 18 years to 35 years. The mean age was 23.64 years. Majority of women (47\%) were in the age group of 20 to 25 years.

Table 2: Distribution based on obstetrics score.

\begin{tabular}{|lll|}
\hline Obstetrics score & Frequency & Percent \\
\hline Primi gravida & 39 & 39.0 \\
\hline Multi gravida & 61 & 61.0 \\
\hline Total & 100 & 100.0 \\
\hline
\end{tabular}

In our study 39 women were primigravidas and 61 were multigravida.

Table 3: Distribution based on gestational age.

\begin{tabular}{|lll|}
\hline Gestational age & Frequency & Percent \\
\hline $28-32$ weeks & 51 & 51.0 \\
\hline $33-36$ weeks & 14 & 14.0 \\
\hline $37-40$ weeks & 31 & 31.0 \\
\hline $41-43$ weeks & 04 & 04.0 \\
\hline Total & 100 & 100.0 \\
\hline
\end{tabular}

The average gestational age was 33.8 weeks, ranging from 28 weeks to 43 weeks. Majority of the patient were $(51 \%)$ in 28 -32 weeks of gestation. In 100 cases 65 were preterm, 31 patients were belonged to $37-40$ weeks of gestation, 4 patients were with prolonged pregnancy.

Table 4: Distribution based on Bishop's score.

\begin{tabular}{|lll|}
\hline Bishops score & Frequency & Percent \\
\hline 1 & 13 & 13.0 \\
\hline 2 & 34 & 34.0 \\
\hline 3 & 40 & 40.0 \\
\hline 4 & 13 & 13.0 \\
\hline Total & 100 & 100.0 \\
\hline
\end{tabular}

Bishops score was determined before inducing with misoprostol. In our study Bishop's score ranged from 1 to 4 and the mean Bishop score was 2.53. 
Table 5: Distribution based on total dose of misoprostol.

\begin{tabular}{|lll|}
\hline Doses & Frequency & Percent \\
\hline $1=50 \mu \mathrm{g}$ & 29 & 29.0 \\
\hline $2=100 \mu \mathrm{g}$ & 31 & 31.0 \\
\hline $3=150 \mu \mathrm{g}$ & 19 & 19.0 \\
\hline $4=200 \mu \mathrm{g}$ & 10 & 10.0 \\
\hline $5=250 \mu \mathrm{g}$ & 5 & 5.0 \\
\hline $6=300 \mu \mathrm{g}$ & 6 & 6.0 \\
\hline Total & 100 & 100.0 \\
\hline
\end{tabular}

Majority of the women delivered with 1 to 2 doses of misoprostol (60\%). Among 100 cases 29 women delivered with 1 dose of misoprostol, 31 with 2 doses, 19 with 3 doses, 10 with 4 doses, 5 with 5 doses and 6 patients required total 6 doses to deliver.

Table 6: Distribution based on side effects.

\begin{tabular}{|ll|l|}
\hline Side effects & Frequency & Percent \\
\hline Nil & 91 & 91.0 \\
\hline Atonic PPH & 2 & 2.0 \\
\hline Chills & 1 & 1.0 \\
\hline Post-partum pyrexia & 4 & 4.0 \\
\hline Retained placenta & 2 & 2.0 \\
\hline Total & 100 & 100.0 \\
\hline
\end{tabular}

There were no side effects seen in $91 \%$ of cases. Postpartum fever was seen in 4 cases and chills was seen in one case. Two patient had atonic PPH which was treated with uterotonics. There was retained placenta in 2 cases which were removed manually. None of the cases had uterine hyper tonicity or tachysystole. No gastrointestinal side effects were seen.

Table 7: Distribution based on induction delivery interval in hours.

\begin{tabular}{|lll|}
\hline IDI & Frequency & Percent \\
\hline Up to 6 hours & 10 & 10.0 \\
\hline $6-12$ hours & 37 & 37.0 \\
\hline $12-18$ hours & 24 & 24.0 \\
\hline $18-24$ hours & 15 & 15.0 \\
\hline$>24$ hours & 14 & 14.0 \\
\hline Total & 100 & 100.0 \\
\hline
\end{tabular}

- Minimum induction to delivery interval is 4 hours

- Maximum induction to delivery interval is 38 hours 40 minutes

- Mean induction to delivery interval is 14 hours 68 minutes.

All women delivered vaginally, the success rate of this regimen is $100 \%$. Fourty seven percent of women delivered within 12 hours, $86 \%$ of women delivered within 24 hours and 100\% women delivered within 40 hours of initiation of induction.
Multiple regression analysis is used to compare the different factors that may affect induction to delivery interval.

Table 8: Relation between induction delivery interval in minutes and maternal age.

\begin{tabular}{|llll|}
\hline Age group & Mean & Number & $\begin{array}{l}\text { Standard } \\
\text { deviation }\end{array}$ \\
\hline Up to 20 years & 1119.73 & 26 & 550.40 \\
\hline 21 - 25 years & 841.87 & 47 & 536.53 \\
\hline 26 - 30 years & 735.50 & 24 & 355.37 \\
\hline 31 - 35 years & 812.33 & 3 & 458.83 \\
\hline Total & 887.70 & 100 & 514.56 \\
\hline
\end{tabular}

The maternal age ranged from 18 to 35 years. In our study, significant correlation was found between induction to delivery interval and maternal age $(\mathrm{P}=$ 0.001). We observed that induction delivery interval decreases as maternal age increases. This may be due to increase in parity of women as age advances.

Table 9: Relation between induction delivery interval and obstetrics score.

\begin{tabular}{|c|c|c|c|}
\hline \multirow{2}{*}{$\begin{array}{l}\text { Induction } \\
\text { delivery } \\
\text { interval }\end{array}$} & \multicolumn{2}{|c|}{ Obstetrics score } & \multirow{2}{*}{ Total } \\
\hline & Primi & Others & \\
\hline Up to 6 hours & $1(2.6 \%)$ & $9(14.8 \%)$ & $10(10.0 \%)$ \\
\hline $6-12$ hours & $10(25.6 \%)$ & $27(44.3 \%)$ & $37(37.0 \%)$ \\
\hline $12-18$ hours & $6(15.4 \%)$ & $18(29.5 \%)$ & $24(24.0 \%)$ \\
\hline $18-24$ hours & $13(33.3 \%)$ & $2(3.3 \%)$ & $15(15.0 \%)$ \\
\hline$>24$ hours & $9(23.1 \%)$ & $5(8.2 \%)$ & $14(14.0 \%)$ \\
\hline Total & $39(100.0 \%)$ & $61(100.0 \%)$ & $100(100.0 \%)$ \\
\hline
\end{tabular}

In our study $11 \%$ of primigravidas delivered within 12 hours as compared to $36 \%$ of multigravidas. $40 \%$ of primigravidas delivered within 24 hours as compared to $56 \%$ of multigravidas. $23 \%$ of primigravidas took $>24$ hours to deliver as compared to $8.2 \%$ of multigravidas.

Table 10: Comparison of mean induction delivery interval to obstetric score.

\begin{tabular}{|lllll|}
$\begin{array}{l}\text { Obstetrics } \\
\text { score }\end{array}$ & Number & $\begin{array}{l}\text { Mean } \\
\text { (minutes) }\end{array}$ & $\begin{array}{l}\text { Standard } \\
\text { deviation }\end{array}$ & $\begin{array}{l}\text { Standard } \\
\text { error of } \\
\text { mean }\end{array}$ \\
\hline Primi & 39 & 1131.36 & 544.95 & 87.26 \\
\hline Others & 61 & 731.92 & 430.73 & 55.15 \\
\hline
\end{tabular}

$\mathrm{P}$ value -0.01 .

The mean induction to delivery interval in multigravidas was 12.1 hours and in primigravidas was 18.8 hours. Mean induction delivery interval was less in multigravidas as compared to primigravida and this was statistically significant in our study $(\mathrm{P}=0.01)$. 
Table 11: Comparison of mean induction delivery interval to gestational age.

\begin{tabular}{|llll|}
\hline $\begin{array}{l}\text { Gestational } \\
\text { age }\end{array}$ & Mean & Number & $\begin{array}{l}\text { Std. } \\
\text { deviation }\end{array}$ \\
\hline 28 - 32 weeks & 814.33 & 51 & 429.47 \\
\hline 33 - 37 weeks & 1077.05 & 19 & 645.50 \\
\hline$>37$ weeks & 892.50 & 30 & 542.47 \\
\hline Total & 887.70 & 100 & 514.56 \\
\hline
\end{tabular}

The gestational age ranged from 28 to 43 weeks. The mean gestational age was 33.84 weeks. The induction to delivery interval and gestational age were correlated and found that there was no significant correlation between mean induction to delivery interval and gestational age $(\mathrm{P}$ $=0.16)$.

Table 12: Comparison of mean induction delivery interval to total dose of misoprostol.

\begin{tabular}{|llll|}
\hline Total dose & Mean & Number & Std. deviation \\
\hline 1.00 & 410.00 & 29 & 88.24 \\
\hline 2.00 & 695.87 & 31 & 117.48 \\
\hline 3.00 & 1014.26 & 19 & 164.61 \\
\hline 4.00 & 1400.00 & 10 & 122.34 \\
\hline 5.00 & 1792.00 & 5 & 135.90 \\
\hline 6.00 & 2179.50 & 6 & 138.11 \\
\hline Total & 887.70 & 100 & 514.56 \\
\hline P value -0.03. & & & \\
\hline
\end{tabular}

There was significant correlation between mean induction delivery interval and total dose of misoprostol used $(\mathrm{P}=$ 0.03).

\section{Induction to delivery interval and Bishop score relation}

The mean bishop score in our study group was 2.53 and ranged from 1 to 4 . Bishop score does affect the mean induction to delivery interval and is statistically significant $(\mathrm{P}=0.03)$.

Our low dose vaginal misoprostol regimen had $100 \%$ success rate with a mean induction to delivery interval of 14.68 hours. This interval is affected by age of the patient, parity and Bishop's score. But gestational age and uterine size does not seem to affect induction delivery interval. This regimen is well tolerated and had minor side effects like fever and chills in 5\% of cases, $2 \%$ women required manual removal of placenta and atonic $\mathrm{PPH}$ was seen in $2 \%$ of cases.

\section{DISCUSSION}

Several methods of induction of labor following late IUFD have been described in literature. Our study was aimed to see the effectiveness of low dose vaginal misoprostol for induction of labour in case of IUFD after 28 weeks of gestation and to compare this to other described regimen in the literature and to assess how our regimen performs among our population. In our study we used the dose regimen of vaginal misoprostol $50 \mu \mathrm{g}$ every 6 th hourly up to maximum of 6 doses. All the women in our study group delivered vaginally with the mean induction to delivery interval of 14.68 hours. Our study showed that this regimen is very effective and safe method to induce labor in late IUFD with minimal side effects. As this regimen is cost effective, it is also suitable for our socio economical set up.

Table 13: Average IDI of different regimens using misoprostol.

\begin{tabular}{|c|c|c|c|}
\hline Reference study & Gestational age (weeks) & Regimen & $\begin{array}{l}\text { Induction to delivery } \\
\text { interval (hours) }\end{array}$ \\
\hline Draycott et $\mathrm{Al}^{3}$ & $24-41$ & $100 \mu \mathrm{g}$ PV maximum of 6 doses & 10 \\
\hline Fletcher et al ${ }^{4}$ & $24-40$ & $100 \mu \mathrm{g}$ PV, $24^{\text {th }}$ hourly & 11.9 \\
\hline Bulgaho et al ${ }^{5}$ & $18-40$ & $100 \mu \mathrm{g}$ PV, $12^{\text {th }}$ hourly & 12.6 \\
\hline L.Nynde et al ${ }^{6}$ & $20-41$ & $200 \mu \mathrm{g} 6^{\text {th }}$ hourly PV maximum 4 doses & 13.5 \\
\hline Ezechi et al ${ }^{7}$ & $>28$ & $100 \mu \mathrm{g}$ PV $12^{\text {th }}$ hourly & 14.18 \\
\hline Srisomboon et $\mathrm{Al}^{8}$ & $14-28$ & $1200 \mu \mathrm{g}, 12$ hrly PV & 15 \\
\hline Marian Neto et al ${ }^{9}$ & $19-41$ & $400 \mu \mathrm{g}$ PV $4^{\text {th }}$ hourly & 17.6 \\
\hline Chittareon $\mathrm{A}$ et al ${ }^{10}$ & $16-41$ & $200 \mu \mathrm{g}$ PV $12^{\text {th }}$ hourly & 18.8 \\
\hline Maria Isabel de et al ${ }^{11}$ & $>22$ & $50-400 \mu \mathrm{g} 6-12$ hrly & 20.1 \\
\hline EL.Gharib et al ${ }^{12}$ & $20-41$ & $25 \mu \mathrm{g} 4^{\text {th }}$ hourly maximum 6 doses & 21 \\
\hline MA.Abdul et al ${ }^{13}$ & $\begin{array}{l}>14-20 \\
20-26 \\
>28\end{array}$ & $\begin{array}{l}400 \mu \mathrm{g} 12^{\text {th }} \text { hrly } \\
200 \mu \mathrm{g} 12^{\text {th }} \text { hrly } \\
50 \mu \mathrm{g} 66^{\text {th }} \text { hrly maximum } 4 \text { doses }\end{array}$ & $\begin{array}{l}15.1 \\
9.2 \\
18.5\end{array}$ \\
\hline Our study & $>28$ & $50 \mu$ g,every $6^{\text {th }}$ hourly PV & 14.68 \\
\hline
\end{tabular}


In our study the mean induction to delivery interval was 14.68 hours. This was comparable to previous studies using different dose regimen of vaginal misoprostol. The observation shows that higher and frequent doses of misoprostol decreases induction to delivery interval.

Bugalho et al found a quicker uterine response in women with more advanced gestation.Study done by EL. ${ }^{5}$ Gharib et al, and Ezechi et al also shows that induction delivery interval is inversely proportional to gestational age. .,12 $^{-12}$ Uterine sensitivity to misoprostol is known to increase with advancing gestation.

We had 30 patients with gestation of 37 weeks or more and mean induction to delivery among these women was 14.8hrs hours, 19 patients with gestation of 33-37 weeks had mean induction to delivery interval of 17.9 hours and 51 patients with 28-32 weeks of gestation had mean induction to delivery interval of 18.5 hours. With this observation it appears that induction to delivery interval decreases with advanced gestation, but when multiple regression analysis was used we found no significant correlation between mean induction to delivery interval and gestational age (P- 0.16$)$.
Table 14: Mean maternal age and mean induction delivery interval.

\begin{tabular}{|lll|}
\hline Study & $\begin{array}{l}\text { Maternal } \\
\text { age } \\
\text { (years) }\end{array}$ & $\begin{array}{l}\text { Mean Induction } \\
\text { to delivery } \\
\text { interval (hours) }\end{array}$ \\
\hline EL.Gharib et al $^{12}$ & 25.5 & 21 \\
\hline Maria Isabel de et al $^{11}$ & 26.1 & 20.1 \\
\hline L.Nynde et al $^{6}$ & 26.4 & 13.5 \\
\hline MA.Abdul et al & 26.7 & 14.6 \\
\hline Ezechi et al & 27.1 & 14.18 \\
\hline Our study & 23.65 & 14.68 \\
\hline
\end{tabular}

Induction delivery interval decreases as maternal age increases. This may be due to increase in parity of women as age advances. In our study significant correlation was found between induction to delivery interval and maternal age $(\mathrm{P}=0.001)$. This trend of decrease in induction delivery interval with maternal age was also seen in other studies.

Table 15: Misoprostol dose and side effects.

\begin{tabular}{|c|c|c|c|c|c|c|c|}
\hline Study & Dose & $\begin{array}{l}\text { Gastro } \\
\text { intestinal } \\
\text { effects }\end{array}$ & $\begin{array}{l}\text { Other minor } \\
\text { side effects } \\
\text { (fever, chills) }\end{array}$ & $\begin{array}{l}\text { Retention } \\
\text { of } \\
\text { placenta }\end{array}$ & PPH & $\begin{array}{l}\text { Total } \\
\text { Side } \\
\text { effects }\end{array}$ & $\begin{array}{l}\text { Induction } \\
\text { delivery } \\
\text { interval (hrs }\end{array}$ \\
\hline EL.Gharib et al ${ }^{12}$ & $25 \mu \mathrm{g} 4^{\text {th }}$ hourly & $15 \%$ & $5 \%$ & $5 \%$ & - & $30 \%$ & 21.36 \\
\hline Maria Isabel de et al & $50-400 \mu \mathrm{g} 6-12$ hrly & $5 \%$ & $2 \%$ & $31.4 \%$ & $2 \%$ & $40 \%$ & 20.1 \\
\hline Gomez et al ${ }^{14}$ & $50 \mu \mathrm{g} 4^{\text {th }}$ hourly PV & $35 \%$ & $7 \%$ & - & & $42 \%$ & 15.2 \\
\hline MA.Abdul et al ${ }^{13}$ & $50 \mu \mathrm{g} 6^{\text {th }}$ hourly PV & $14 \%$ & - & $4 \%$ & - & $18 \%$ & 14.6 \\
\hline Ezechi et al ${ }^{7}$ & $100 \mu \mathrm{g} 12^{\text {th }}$ hourly & $2.7 \%$ & $2 \%$ & $5.4 \%$ & $8 \%$ & $19 \%$ & 14.18 \\
\hline L.Nynde et al ${ }^{6}$ & $200 \mu \mathrm{g} 6^{\text {th }}$ hourly & $15 \%$ & $5 \%$ & - & - & $20 \%$ & 13.5 \\
\hline Our study & $50 \mu \mathrm{g} 6^{\text {th }}$ hourly & - & $5 \%$ & $2 \%$ & $2 \%$ & $9 \%$ & 14.68 \\
\hline
\end{tabular}

Our regimen carried no gastrointestinal side effects like nausea, vomiting or diarrhoea, but in $5 \%$ cases minor side effects like fever, chills were noted. Retained placenta was another complication which was noted in $2 \%$ of the cases in our study. These cases were managed by manual removal of placenta. This has been observed in other studies also and rate of placental retention was observed more with lesser gestational age. Two cases in the study group had atonic post-partum haemorrhage (2\%) which was controlled by uterotonics. In our study we did not encounter any women with uterine tachysystole or hypertonic uterine contraction because of usage of low dose of the drug. The side effects rate of our study is $9 \%$ which is less compared with previous studies. So by using low dose misoprostol we can achieve delivery within reasonable time period with significantly less side effects.
In Bulgaho et al, study the success rates ranged from $67 \%$ to $100 \%$. Gharib EL et al, study had success rate of $90 \%$. Our study has success rate of $100 \% .^{5,12}$

The side effects can be minimized by vaginal administration of relatively low dose. The side effects and the requirement of dose of misoprostol can also be reduced by using oxytocin along with it.

\section{CONCLUSION}

The low dose vaginal misoprostol is a safe and effective method for induction of labor following IUFD after 28 weeks of gestation. The induction to delivery interval is shorter with lesser side effects. But further studies are needed to determine the optimum dose of misoprostol. 
Funding: No funding sources

Conflict of interest: None declared

Ethical approval: The study was approved by the Institutional Ethics Committee

\section{REFERENCES}

1. Pritchard JA. fetal death. Inutero Obstet Gynecol. 1959;14:573-80.

2. Dodd JM, Crowther CA. Misoprostol for induction of labour to terminate pregnancy in the second or third trimester for women with a fetal anomaly or after intrauterine fetal death. Cochrane Database of Systematic Review. 2010;4:CD004901:1-11.

3. Draycott T, Hawkes N, Read MD. Induction of labor with vaginal misoprostol after intrauterine death from 24 weeks gestation. J Obstet Gynecol. 1996;16:517-8.

4. Fletcher HM, Wharfe G, Simeon D, Mitchell S, Brown D. Induction of labour with intra vaginal misoprostol versus dinoprostone in intrauterine death: a retrospective study. J Obstet Gynecol. 1996;16:155-8.

5. Bugalho A, Bique C, Machungo F, Faundes A. Induction of labour with intravaginal misoprostol in intrauterine fetal death. Am J Obstet Gynecol. 1994;171:538-41.

6. Nyende L, Towobola OA, Mabina MH. Comparison of vaginal and oral misoprostol, for the induction of labour in women with intra-uterine foetal death. 2004;81(4)179-82.

7. Ezechi OC, Kalu BK, Ndububa VI, Nwokoro CA. Induction of labour by vaginal misoprostol for intra uterine fetal death. J Obstet Gynaecol Ind. 2004;54(6).
8. Srisomboon J, Pongpisuttinun S. efficacy of intracervico-vaginal misoprostol in second trimester pregnancy termination: a comparison between live and dead fetus. J Obstet Gynecol Res. 1998;24:1-5.

9. Mariani NC, Leão EJ, Barreto EM, Kenj G, De Aquino MM, Tuffi VH. Use of misoprostol for labor induction in stillbirth. Rev Paul Med. 1987;105:3258.

10. Isabel do Nascimento $M$, de Almeida Cunha A, Regina dos Santos S, Oliveira M, Gonzaga Nunes G, Alvarez FS, et al. Misoprostol use under routine conditions for termination of pregnancies with intrauterine fetal death. 2013;59(4):354-9.

11. Chittacharoen A, Herabutya Y, Punyavachira P. A randomized trial of oral and vaginal misoprostol to manage delivery in cases of fetal death. Obstet Gynecol. 2003;101(1):70-3.

12. El-Gharib MN, El-Ebyary MT, Alhawary TS, Elshourbagy SH. Low dose vaginal misoprostol in the management of women with intrauterine fetal death. Clinical Medicine insights: Women's Health 2010;3:15-21.

13. Stanton C, Lawn JE, Rahman H, WilczynskaKetende K, Hill K. Stillbirth rates: delivering estimates in 190 countries. Lancet. 2006;367:148794.

14. Gomez ponce de leon R, Wing D, Fiala-Misoprostol C. For intra uterine fetal death. Inter J Gynecol Obst. 2007;99:S190-193.

Cite this article as: Tharihalli C, Bhat S. Study of vaginal misoprostol for labour induction in intra uterine fetal demise. Int J Reprod Contracept Obstet Gynecol 2017;6:479-84. 